\title{
Trasferring territorial governance in the European Union: Why, what, how and through whom?
}

\author{
Giancarlo Cotella \\ Interuniversity Department of Regional and Urban Studies and Planning \\ Politecnico di Torino. \\ 39 Viale Mattioli, Torino, Italy \\ giancarlo.cotella@polito.it
}

\begin{abstract}
The field of policy transfer is highly complex. This is particularly true when it comes to territorial governance which is a process integrating several context-dependent policy fields rather than a policy per se. The contribution adopts a conceptual framework developed within the project ESPON TANGO to reflect upon this matter. In particular, it conceptualises distinct modes of policy transfer in the EU, explaining many ways through which a certain territorial governance practice in a given domestic context can reach other context(s) that may apply it. The presented framework is expected to help define what to transfer, how and through whom; in other words (i) what territorial governance elements may be effectively transferred, (ii) what interactive resources may favour the transfer and (iii) what 'receiving' stakeholders' group(s) may constitute the target. Building on this assumption, the contribution reflects upon the potential transferability of territorial governance 'features', intended as practical manifestation of good territorial governance in real cases.
\end{abstract}

Keywords: territorial governance, policy transfer, good practices, European Union, Europeanization, ESPON.

\section{Introduction}

The assumption that the dissemination of practices can lead to policy change "has become an accepted wisdom within national policies and programmes, as well as in international arenas and networks" (Bulkeley, 2006: 1030). This is evident when looking at recent European Union (EU) policy documents highlighting how the identification and dissemination of good practices is pivotal to many areas of European policy (e.g. CEC, 2006). Willing to provide a contribution in this respect the research project ESPON TANGO Territorial Approaches for New Governance ${ }^{1}$ aimed, among others, at developing practical advice for territorial governance based on evidence from current practices. However, this proved to be a mind-ravelling task: territorial governance processes are intrinsically complex and made up of a lot of key dimensions and it is highly questionable whether

\footnotetext{
1 The ESPON TANGO project is pursued by a consortium led by Nordregio and composed by the following partners: Delft University of Technology, University of Newcastle upon Tyne, Politecnico di Torino, Research Centre for Economic and Regional Studies (Hungarian Academy of Sciences); University of Ljubljana (http://www.espon.eu/main/Menu_Projects/ Menu_AppliedResearch/tango.html).
} 
any territorial governance practice is entirely 'good' or 'bad', being rather a mix of successful (from which something can be learned) and unsuccessful (in which the lesson comes from the recognition of the causes of failure) features.

If so, the problem of spreading good territorial governance can be profitably defined in terms of identification and transferability of its successful features. In this light, the main research questions addressed by this contribution are the following:

(i) What are the main features of territorial governance emerging from empirical analysis that are potentially to be transferred?

(ii) What are the conditions in which each single feature may constitute a trigger for learning in other contexts, i.e. how and through whom could it be possibly transferred?

First, the author presents the working definition of territorial governance adopted by the ESPON TANGO research team. Then, he introduces a conceptual framework to allow better understanding of policy transfer in the context of EU territorial governance. Next, he illustrates the territorial governance promoters and inhibitors obtained aggregating the features identified from the project's case studies. Finally, he addresses each of them to a specific mode of transfer, and therefore to a specific target audience. A conclusive section rounds off the contribution and sketches out future research perspectives.

\section{Territorial governance: a working definition}

The Treaty on the Functioning of the European Union (Art. 174) mentions that in order to promote its overall harmonious development the EU shall develop and pursue its actions leading to the strengthening of its economic, social and territorial cohesion. The organisation of territorial development is however no piece of cake as territories are shaped by a complex tissue of decisions taken at different administrative levels, for different sector policies and by different types of public and private actors. The concept of territorial governance stands here as describing the political ambition to coordinate policies, programmes and projects in relation to territorial development. A recent addition to the governance and multi-level governance debate (cf. Pierre and Peters 2000; Stoker, 1998; Hooghe and Marks 2001, 2003), it focuses more on how these concepts have infiltrated and been interpreted in the territorial debate and has become an increasingly important aspect of policy actions in Europe (Janin Rivolin 2010; Faludi 2012).

Despite recent achievements, however, the territorial governance debate continues to build on traditional governance discourses. For instance, when defining territorial governance as " [...] the process of organization and coordination of actors to develop territorial capital in a non-destructive way in order to improve territorial cohesion at different levels", Davoudi et al (2008: 37) the term is largely conceptualised based on 'regular' governance theories, at the same time making the call for the development of a theory of territorial governance to be tested through new empirical analysis. In order to partially provide an answer to this need and to develop a working definition of territorial governance to build the various research activities upon, the ESPON TANGO consortium drew together various cornerstones from the literature as regards what is perceived as being most essential and inherent in the notion of territorial governance.

The starting point has been the argument by Davoudi et al (2008: 352-353) who claim, building on the results of the ESPON 2.3.2 project (ESPON, 2007), that territorial governance implies both horizontal and vertical coordination and can be analysed by looking at three broad types of 
factors: (i) the structural context, (ii) the policies of the institutional realm and (iii) the results and processes of actions, programmes and projects for territorial cohesion. This makes the territorial governance to be considered an organization of new "constellations of actors, institutions and interests" (Gualini 2008: 16), both between units of government and between governmental and nongovernmental actors, and raises in turn the questions of integration of relevant policy sectors and the coordination of such actors, in particular in a multi-level perspective. In addition, the consortium addressed the recent debate around the concept of resilience of social systems and their adaptability to changing contexts (e.g. economic crisis, natural disasters), building on Gupta et al. (2010) idea of 'adaptive institutions', i.e. institutions that encourage learning among actors by questioning the socially embedded ideologies, frames, assumptions, roles, rules and procedures that dominate problem-solving efforts. Another key dimension of territorial governance emerges when factoring in the claims of participation, partnership and inclusion of relevant stakeholders that are expressed in particular in the spatial planning literature since the late 1980s (cf. Healey 1997), in other words to mobilise stakeholder participation and thus activate their specific knowledge and incorporate their claims and concerns in the formulation and implementation of territorial development public policies, programmes and projects. Similarly, being sensitive to Jordan's argument over the lack of geographical specificity of contemporary conceptualizations of governance (2008: 21), the consortium devoted particular attention to the extent to which place-based/territorial specificities and characteristics are addressed within territorial governance practices.

Based on the above elements, the ESPON TANGO working definition of territorial governance has been formulated as follows:

Territorial governance is the formulation and implementation of public policies, programmes and projects for the development ${ }^{2}$ of a placelterritory $y^{3}$ by: (i) integrating relevant policy sectors, (ii) co-ordinating the actions of relevant actors and institutions, particularly considering multi-level interplay, (iii) mobilising stakeholder participation, (iv) being adaptive to changing contexts, (v) addressing the place-based/territorial specificities and characteristics.

(ESPON 2012: 11)

\section{Transferring territorial governance in the $\mathbf{E U}$ : a conceptual framework}

The transferability of territorial governance is an issue characterised by a high degree of complexity, difficulty and risk of failure. Reasons behind this situation are primarily linked to the field of policy transfer in general, and may be referred to (i) the questionability of 'reproductive' assumptions behind the rhetoric of 'best practices transferability', especially where this concerns diversified institutional contexts (James \& Lodge, 2003; Vettoretto, 2009; Stead, 2012) and (ii) the lack of verified and tested universal models for policy transfer because of the high degree of variables at stake (Dolowitz \& Marsh, 2000). An additional complexity is related to the very nature of territorial governance, which

\footnotetext{
2 Development is here defined as the improvement in the efficiency, equality and environmental quality of a place/territory, in line with the Europe 2020 strategy (CEC, 2010).

3 Territory/place is here intended as a social construct, not necessarily limited by jurisdictional boundaries.
} 
is the result of a complex multi-level and multi-actor process integrating several policies rather than a 'policy' per se, aimed at achieving specific territorial development goals.

In order to profitably address the issue of territorial governance transferability, the latter is here framed in the institutional domain of EU territorial governance with the purpose of reducing conceptual complexity as far as possible. Building on a proficient debate regarding (the design of) institutions in/for spatial planning (cf. among others: Alexander, 1995; Healey, 1999, 2006; Gualini, 2001; Moulaert, 2005; Verma, 2007), territorial governance may indeed be described as an institutional phenomenon, the end-product of a creative selection process of trial and error based on "(i) the generation of variety (in particular, a variety of practices); (ii) the reduction of this variety via competition and selection (the discourse); (iii) the propagation and persistence of the selected solution (the system of rules)" (Moroni, 2010: 279).

These inputs have been recently adopted for purpose of conceptualisation in comparative analyses, leading to a description of the evolutionary operation of territorial governance in any institutional context as occurring through cyclical processes variously interconnecting four analytical dimensions - practices, discourse, structure and tools - through stages of social experience, political sharing and institutional codification (Janin Rivoln 2012). A tentative application of this analytical model to the process of 'Europeanization' (Knill \& Lehmkuhl, 1999; Olsen, 2002; Radaelli, 2004; Lenschow, 2006), has led to further interesting findings (see Cotella \& Janin Rivolin, 2010; 2012), presenting the EU institutional context as characterised by the simultaneous activity of one supranational cycle (the EU) and various domestic cycles (as many as the EU Member States) (see figure 1). As several authors pointed out already, policy transfer in Europe is intimately connected with the process of Europeanization (Wishlade et al., 2003; Holzinger \& Knill, 2005). The proposed analytical framework is therefore assumed to be of some value in framing conceptually the main opportunities for transferring 'good practices' in the domain of EU territorial governance, on the basis of the hypothesis that "the [EU] apparatus of policy diffusion and development has transnationalised in such a profound and irreversible way as to render anachronistic the notion of independent, 'domestic' decision-making” (Peck, 2011: 774). 


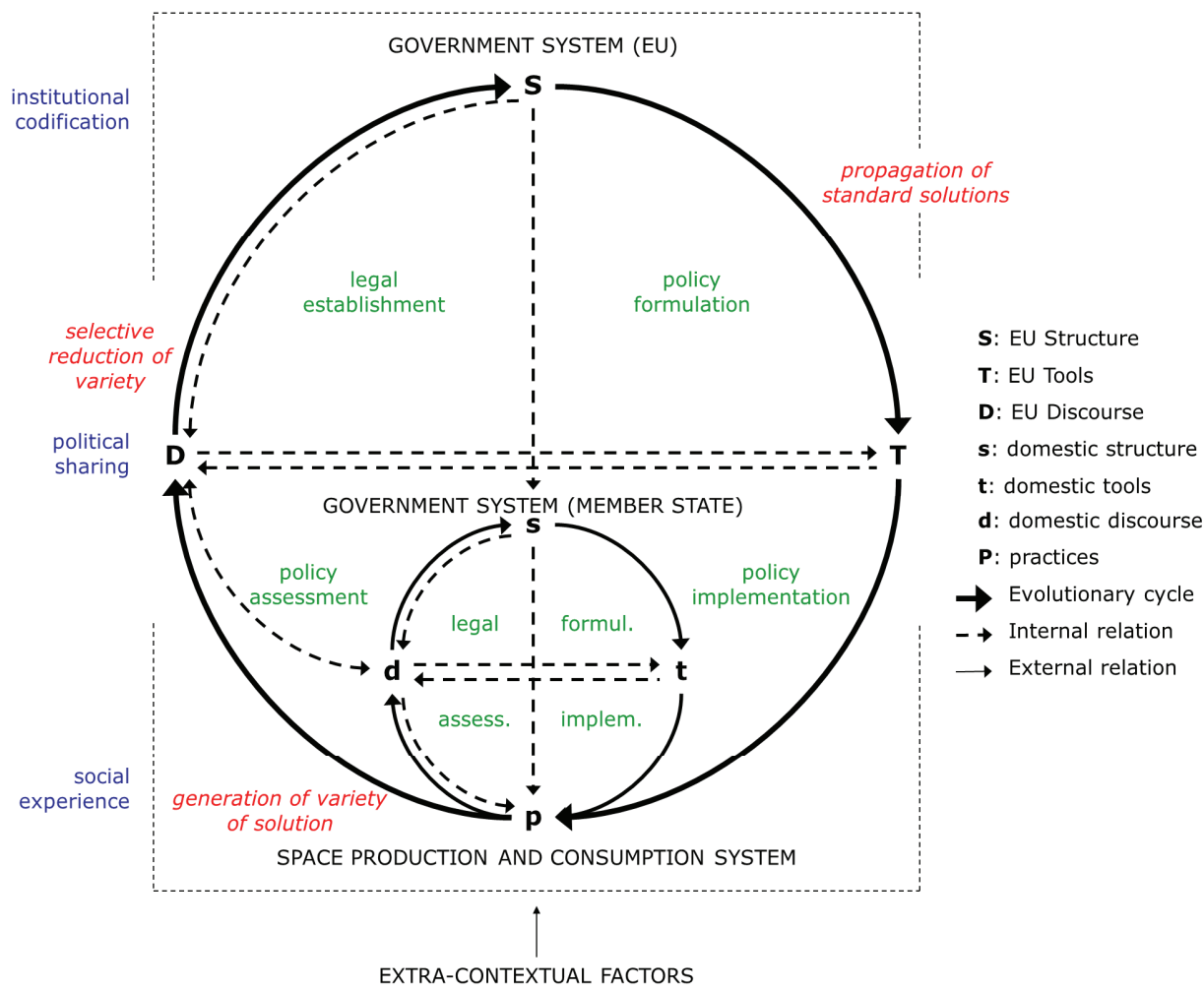

Figure 1. EU territorial governance process of change (adaptation on: Cotella \& Janin Rivolin, 2010, 2012)

If so, the EU territorial governance process of change presented above may be used as a background for conceptualisation of the possible paths that policy transfer can be expected to take from a 'good practice' ( $\mathrm{p} 1$, in a certain domestic context) to supposed receiving context(s) (p2/n, in one or more different domestic contexts). The first observation in this respect is that the initial step of these possible paths is anyhow directed from $\mathrm{p}(1)$ to $\mathrm{D}$, that is from the supposed good practice to the 'EU discourse', i.e. the virtual place in which single social experiences are filtered and shared, via selection by policy assessment, in the form of ideas and proposals for good territorial governance at the EU level (e.g. the ESPON platform, but also the activities of the National Territorial Cohesion Contact Points. Adams et al 2011). This means that possible modes for spreading territorial governance in Europe are all pivoted on the activity of a EU discourse on territorial governance, more or less structured and coherent, and are distinguishable for the different paths that ideas and proposals can take from here in order to reach and influence other social experiences ( $\mathrm{p} 2 / \mathrm{n})$. In particular, three distinct transfer modes are identifiable, on the basis of the assumption that ESPON TANGO plays an active role in the discourse about the formation of EU Territorial Governance, being engaged in a critical study of managing place-based/territorial policies, projects and programmes and as such focussing on a number of original practices (p1, i.e. the case studies) in order to identify their 'good' features and profitable ways to favour their transfer in other practices in different domestic contexts (p2/n) (Figure 2). 


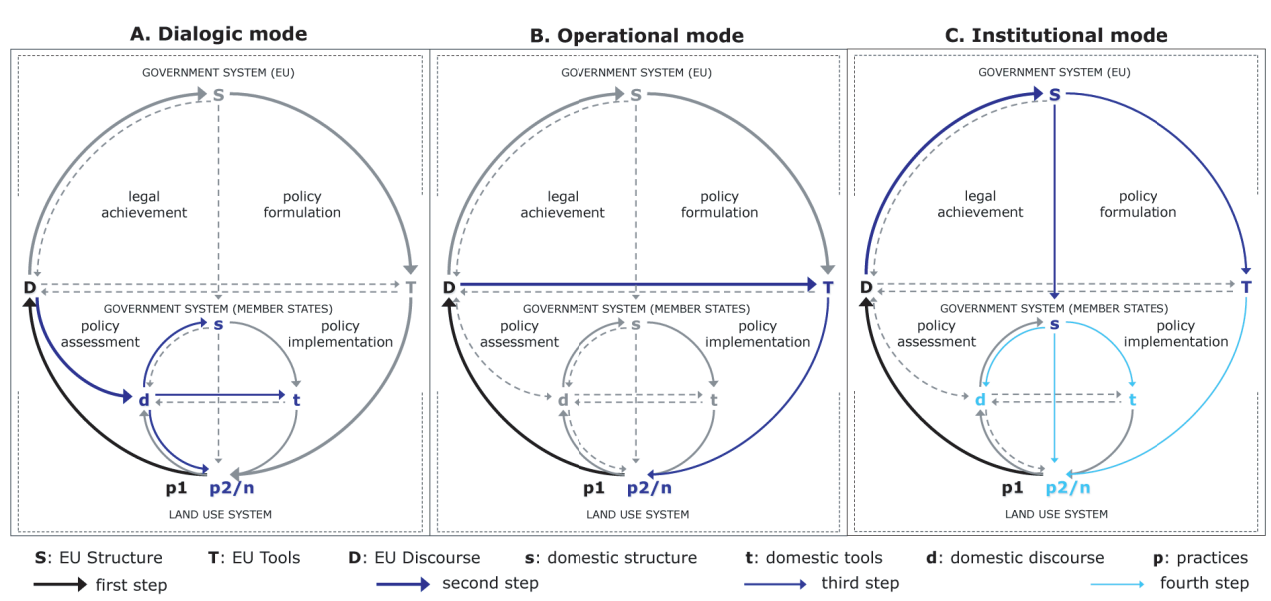

Figure 2. Transfer modes of (good) territorial governance in Europe Source: Janin Rivolin \& Cotella, 2014.

A dialogic mode for transferring good territorial governance initiates with the capacity of the EU discourse to influence one or more domestic discourses $(D \rightarrow d 2 / n)$ and, from here, relevant practices in direct or indirect ways (i.e. via domestic tools or structure). This occurs when "in its 'weakest' form, European policy [...] affects domestic arrangements [...] indirectly, namely by altering the beliefs and expectations of domestic actors. [...] Hence, the domestic impact of European policies is primarily based on a cognitive logic" (Knill \& Lehmkuhl, 1999: 2). This kind of discursive integration "can be successful when there are strong policy communities active at European and national levels and direct links between them" (Böhme, 2002: III), with potential borrowers that may exploit the opportunity of voluntarily importing territorial governance practices depending on the actual level of integration of a domestic discourse (d2/n) with the EU discourse (D). A direct declination of the dialogic mode concerns the transfer of features of good territorial governance from the discursive arenas into practices ( $\mathrm{p} 2 / \mathrm{n})$. Domestic practices may be influenced also indirectly in a longer period, if domestic discourse is able to have an effect on domestic structure (s $2 / \mathrm{n})$ or tools ( $2 / \mathrm{n})$.

An operational mode for spreading good territorial governance concerns the transfer of insights gained in the EU discourse into EU tools $(\mathrm{D} \rightarrow \mathrm{T})$, which are then capable of influencing practices in various domestic contexts. This mode is effective insofar as "European influence is confined to altering domestic opportunity structures, and hence the distribution of power and resources between domestic actors" (Knill \& Lehmkuhl, 1999: 1). In practice, features of good territorial governance can be translated into other kinds of components (e.g. methods, techniques, know-how), which are transferred rather "directly" to new potential experiences in various domestic contexts (p2/n) via economic conditionality.

An institutional mode for spreading good territorial governance occurs when the EU discourse is codified within the EU structure $(\mathrm{D} \rightarrow \mathrm{S})$, inducing changes into domestic structures and, from here, to respective practices, or into EU tools with effects described in the operational mode. In this case, "European policy-making may trigger domestic change by prescribing concrete institutional requirements with which member states must comply; that is, EU policy 'positively' prescribes an institutional model to which domestic arrangements have to be adjusted" (Knill \& Lehmkuhl, 
1999: 1). This mode implies that features of good territorial governance are translated into further kinds of components (e.g. rules, codes and laws). Many local experiences may be reached this way through a longer but "enveloping" process of policy transfer, regarding an influence in terms of legal conditionality filtered by domestic structures (s $2 / \mathrm{n}$ ) plus a possible economic conditionality induced by EU tools $(\mathrm{T})$.

This view is compatible with one critique often raised in relation to the transferability of good territorial governance (cf. Wolman and Page, 2002), i.e. that aiming at promoting transferability indiscriminately addressing the general public is most often ineffective; rather it may be more successful to address the transfer of peculiar elements of territorial governance to specific categories of stakeholders. In other words, the hypothesis here is that the various transfer modes described above do not address all potential stakeholders active in the field of territorial development in the same way. On the contrary, each of these modes addresses, primarily but not exclusively, one or more categories of stakeholders. For instance, the institutional mode addresses specifically EU decision makers. Conversely, the technical mode implies the opportunity to transfer features of good territorial governance to EU policy-makers. On its hand, the dialogic mode is particularly concerned with the territorial knowledge communities active in a specific domestic context but, in second instance, may reach any stakeholder active in territorial development in that context: decision-makers, policymakers and practitioners (See table 1).

Table 1. Modes for transfer good territorial governance in Europe

\begin{tabular}{|c|c|c|c|c|c|}
\hline $\begin{array}{l}\text { Transfer } \\
\text { modes }\end{array}$ & $\begin{array}{l}\text { Interactive } \\
\text { resources }\end{array}$ & $\begin{array}{c}\text { Target } \\
\text { beneficiaries }\end{array}$ & $\begin{array}{l}\text { Addressed } \\
\text { dimension }\end{array}$ & $\begin{array}{l}\text { Following paths to } \\
\text { reach the borrowers }\end{array}$ & $\begin{array}{c}\text { Influence } \\
\text { mechanisms }\end{array}$ \\
\hline \multirow{3}{*}{ Dialogic } & $\begin{array}{l}\text { Practices of } \\
\text { implementation }\end{array}$ & Practitioners & $\begin{array}{l}\text { domestic } \\
\text { practices (p) }\end{array}$ & $\mathrm{p} 1 \rightarrow \mathrm{D} \rightarrow \mathrm{d} 2 \mathrm{n} \rightarrow \mathrm{p} 2 \mathrm{n}$ & lesson drawing \\
\hline & $\begin{array}{l}\text { Techniques and } \\
\text { methods for policy- } \\
\text {-making tools }\end{array}$ & $\begin{array}{l}\text { Domestic } \\
\text { policy-makers }\end{array}$ & $\begin{array}{l}\text { Domestic } \\
\text { tools }(\mathrm{t})\end{array}$ & $\mathrm{p} 1 \rightarrow \mathrm{D} \rightarrow \mathrm{d} 2 \mathrm{n} \rightarrow \mathrm{t} 2 \mathrm{n}$ & lesson drawing \\
\hline & $\begin{array}{l}\text { Rules for structuring } \\
\text { TG }\end{array}$ & $\begin{array}{l}\text { Domestic } \\
\text { decision- } \\
\text { makers }\end{array}$ & $\begin{array}{l}\text { Domestic } \\
\text { structure (s) }\end{array}$ & $\mathrm{p} 1 \rightarrow \mathrm{D} \rightarrow \mathrm{d} 2 \mathrm{n} \rightarrow \mathrm{s} 2 \mathrm{n}$ & lesson drawing \\
\hline Operational & $\begin{array}{l}\text { Techniques and } \\
\text { methods for policy- } \\
\text {-making tools }\end{array}$ & $\begin{array}{l}\text { EU } \\
\text { policy-makers }\end{array}$ & EU Tools (T) & $\mathrm{p} 1 \rightarrow \mathrm{D} \rightarrow \mathrm{T} \rightarrow \mathrm{p} 2 \mathrm{n}$ & $\begin{array}{l}\text { Economic } \\
\text { conditionality }\end{array}$ \\
\hline Institutional & $\begin{array}{l}\text { Rules for structuring } \\
\text { TG }\end{array}$ & $\begin{array}{l}\text { EU decision- } \\
\text { makers }\end{array}$ & $\begin{array}{l}\text { EU Structure } \\
\text { (S) }\end{array}$ & $\begin{array}{l}\mathrm{p} 1 \rightarrow \mathrm{D} \rightarrow \mathrm{S} \rightarrow \mathrm{s} 2 \mathrm{n} \\
\mathrm{p} 1 \rightarrow \mathrm{D} \rightarrow \mathrm{S} \rightarrow \mathrm{T} \rightarrow \mathrm{p} 2 \mathrm{n}\end{array}$ & $\begin{array}{l}\text { Legal } \\
\text { conditionality } \\
\text { Economic } \\
\text { conditionality }\end{array}$ \\
\hline
\end{tabular}

Following the argument of Wolman and Page (2002) who define policies as made of various elements that can be exchanged, the transfer of each feature of good territorial governance from one context to others may be seen as depending on different interactive resources that, in turn, may be more relevant for specific categories of stakeholders active in territorial development activities. Linking each territorial governance feature that may potentially be transferred to the category or categories of interactive resources - namely: (i) ideas and principles, (ii) practices of implementa- 
tion, (ii) techniques and methods for policymaking tools, and (iv) rules for structuring territorial governance - which would potentially be more effective in promoting the transfer may therefore allow to link each of these features to the specific group of stakeholders that usually manage those resources. In particular, those promoters that are identified as more easily transferrable through practices of implementation should be primarily addressed to practitioners ${ }^{4}$; those that seems to require techniques and methods for policymaking tools should be addressed to policy-makers ${ }^{5}$; and those that need the codification of rules for structuring territorial governance should addressed to decision-makers ${ }^{6}$. Finally, the promoters whose transfer is considered to potentially occur through ideas and principles should be addressed to all categories of stakeholders.

\section{Promoters and inhibitors of good territorial governance}

In the light of the discussion sketched above, the ESPON TANGO project frames the problem of the identification of good territorial governance practices in terms of identification of their specific and virtuous features, as well as of those elements that may constitute potential barriers for good territorial governance processes to occur. The ESPON TANGO case studies ${ }^{7}$ were used to provide in-depth insights on how territorial governance practices appear to be operational (or not) and thus contribute to (or hamper) the success of the development of a place or territory. More in detail, the results of the analysis were used to generate a number of features of territorial governance. Building on the assumption that each case would include practical characteristics of territorial governance and thus could help to define what features may contribute to 'good' territorial governance and what may undermine it, each research team was asked to identify specific territorial governance promoters that emerged from their case study by referring to the five territorial governance dimensions that constitute the ESPON TANGO working definition of territorial governance. Similarly, they were asked to identify, in relations to each of these five dimensions, one or more inhibitors, i.e. bad features of territorial governance.

On the basis of the territorial governance features gathered for all the twelve case studies, a reduction of complexity of the collected information was operated by aggregating, for each of the

${ }^{4}$ Practitioners of territorial governance are the private or public professionals engaged in various roles concerning activities with a territorial dimension at different scales and cohesion policy programmes or projects in Europe. Practices are the specific resource they 'can manage', since they are protagonists of the creation of interactive knowledge, which is generated from the social experience of territorial governance processes.

5 Policy makers of territorial governance are usually public executives and officials in charge of spatial planning and control activities at various administrative levels in all countries, as well as deputed to implement cohesion policy at the EU level (e.g. officials of the European Commission) or at national, regional and local levels in Member States. Techniques of policymaking, applied through the elaboration of programmes and projects, are the primary resource of which they dispose in order to address territorial governance processes.

${ }^{6}$ Decision makers of territorial governance are those appointed by democratic vote, such as members of the EU Parliament and national parliaments or regional and municipal councils, often in charge of ministerial or departmental roles that are related to spatial planning and to cohesion policy. In reason of their elective position, they are the ones that can establish rules on territorial governance.

7 The ESPON TANGO Project developed the following case studies: 1) Territorial Climate Change governance in the Baltic Sea region; 2) Territorial Governance as a way to resource efficiency in urban development; 3) Coordination of land-use and transport (StedenbaanPlus); 4) Cross-border cooperation Rhine Basin Rhine River basin; 5) Target-based Tripartite Agreement between the European Commission; 6) Innovative economic development strategies in Saint Étienne within the South Loire SCOT framework; 7) Greater Manchester City Region Governance; 8) North Shields Fish Quay: Neighbourhood Planning in the UK; 9) Management of Structural Funds in Central and Eastern European countries; 10) European Capital of Culture; 11) Formulation and implementation of spatial planning strategies and regional development policies in Ljubljana Urban Region; 12) Governance of natural areas in the Alpine Adriatic area Alpine Adriatic area. Further details are available at: http://www. espon.eu/main/Menu_Projects/Menu_AppliedResearch/tango.html. 
five territorial governance dimensions, a list of more 'general' promoters and inhibitors that may be considered to either favour or constrain the occurrence of good territorial governance (see table 2 and 3). Furthermore, the obtained list of promoters was discussed and further reviewed in an ad hoc organized Stakeholders' workshop. The territorial governance promoters represent a number of 'good' territorial governance features that may contribute to generating good territorial governance processes. The inhibitors, on the other hand, constitute a set of 'warnings' for the intended target group (the practitioners, policy and decision maker) being actively involved in various way in territorial governance processes, a sort of 'to-be-avoided' list has been collected based on those features that may undermine good territorial governance processes.

Table 2. List of territorial governance promoters as derived from the case study analysis

\begin{tabular}{|c|c|c|}
\hline Dimension & TG Promoters & Case Studies $^{\mathbf{a}}$ \\
\hline \multirow{14}{*}{$\begin{array}{l}\text { 1. Coordinating } \\
\text { actions of actors } \\
\text { and institutions }\end{array}$} & - Stability of cooperative experiences & $2,4,7,12$ \\
\hline & - Pro-active public organisation & $3 ; 4,10$ \\
\hline & - Motivation & 4,5 \\
\hline & - Capacity of negotiation & 8,11 \\
\hline & - Clear and uncontested leadership & $2,3,6,7,11,12$ \\
\hline & - Self-committed leadership & 1,4 \\
\hline & - Effective strategic framework & 4 \\
\hline & - Political commitment & $9,11,12$ \\
\hline & - Common goals, common history & Stakeholders workshop \\
\hline & - Code of conduct - guidelines & Stakeholders workshop \\
\hline & - Institutional capacity - qualified staff & Stakeholders workshop \\
\hline & - Follow-up - monitoring & Stakeholders workshop \\
\hline & - Leadership at the right level & Stakeholders workshop \\
\hline & - Quality of motivation & Stakeholders workshop \\
\hline \multirow[t]{6}{*}{$\begin{array}{l}\text { 2. Integrating policy } \\
\text { sectors }\end{array}$} & $\begin{array}{l}\text { - Acknowledgement of, and integration with, a multi-level } \\
\text { framework }\end{array}$ & $3,4,5,12$ \\
\hline & $\begin{array}{l}\text { - Political support to policy integration at the appropriate } \\
\text { territorial scale }\end{array}$ & $4,7,11$ \\
\hline & - Spatial tool favouring sectoral integration & $9,10,11$ \\
\hline & - Rationale catalysing integration & 2 \\
\hline & - Involvement of relevant public and private stakeholders & $2,3,4,7$ \\
\hline & $\begin{array}{l}\text { - Organizational routines favouring cross-sector } \\
\text { fertilisation }\end{array}$ & $6,9,11,12$ \\
\hline
\end{tabular}




\begin{tabular}{|c|c|c|}
\hline Dimension & TG Promoters & Case Studies $^{\mathbf{a}}$ \\
\hline \multirow[t]{7}{*}{$\begin{array}{l}\text { 2. Integrating policy } \\
\text { sectors }\end{array}$} & $\begin{array}{l}\text { - Strong political commitment towards a shared territorial } \\
\text { vision }\end{array}$ & $1,2,6,8$ \\
\hline & - Balance between flexibility and legal certainty & 4 \\
\hline & - Monitoring process & Stakeholders workshop \\
\hline & - Win-win situation - interest & Stakeholders workshop \\
\hline & - Effective strategic framework - strategies & Stakeholders workshop \\
\hline & - Leadership - vision & Stakeholders workshop \\
\hline & - Compatible policy sectors & Stakeholders workshop \\
\hline \multirow{11}{*}{$\begin{array}{l}\text { 3. Mobilising } \\
\text { stakeholder } \\
\text { participation }\end{array}$} & - Political commitment & 2,4 \\
\hline & - Usage of various mechanisms of participation & 8,12 \\
\hline & - Mix of indirect and direct democratic legitimacy & 3,11 \\
\hline & $\begin{array}{l}\text { - Mechanisms allowing for broad stakeholders' } \\
\text { involvement }\end{array}$ & $1,2,11$ \\
\hline & - Information flow ensured & 7,9 \\
\hline & $\begin{array}{l}\text { - Effective means of communication/dissemination of } \\
\text { information }\end{array}$ & $2,3,4,6,10,11$ \\
\hline & - High level of accountability & 2 \\
\hline & $\begin{array}{l}\text { - Clear stakeholder process of involvement (mechanisms, } \\
\text { expectation) }\end{array}$ & Stakeholders workshop \\
\hline & $\begin{array}{l}\text { - How to motivate stakeholder (vision, benchmarking, } \\
\text { learning) }\end{array}$ & Stakeholders workshop \\
\hline & - Feedbacks to stakeholders & Stakeholders workshop \\
\hline & - Ownership of questions & Stakeholders workshop \\
\hline \multirow{9}{*}{$\begin{array}{l}\text { 4. Being adaptive to } \\
\text { changing contexts }\end{array}$} & - Co-production of knowledge, knowledge transfer & $4,9,10,11,12$ \\
\hline & - Institutional mechanisms that favour learning & $2,7,10$ \\
\hline & - Feedback procedures & $1,2,3$ \\
\hline & - Institutional mechanisms supporting adaptivity & 6,7 \\
\hline & - Role of people in charge of responsibility & 2 \\
\hline & - Flexibility of governance structure & 3 \\
\hline & - Experience in complex programming & 11 \\
\hline & - Multi-annual programming & Stakeholders workshop \\
\hline & - Involvement, participation, commitment & Stakeholders workshop \\
\hline
\end{tabular}




\begin{tabular}{|c|c|c|}
\hline Dimension & TG Promoters & Case Studies $^{\text {a }}$ \\
\hline \multirow[t]{6}{*}{$\begin{array}{l}\text { 4. Being adaptive to } \\
\text { changing contexts }\end{array}$} & $\begin{array}{l}\text { - Adaptive management (small-steps, flexibility, room to } \\
\text { change direction) }\end{array}$ & Stakeholders workshop \\
\hline & $\begin{array}{l}\text { - Exchanging best practices to understand the right } \\
\text { amount of adaptation }\end{array}$ & Stakeholders workshop \\
\hline & - Methods for attracting change & Stakeholders workshop \\
\hline & - Power to decide change at the right level & Stakeholders workshop \\
\hline & - Integrative holistic approach & Stakeholders workshop \\
\hline & - Being conscious and being inspired & Stakeholders workshop \\
\hline \multirow{14}{*}{$\begin{array}{l}\text { 5. Realising place- } \\
\text { based/ territorial } \\
\text { specificities and } \\
\text { impacts }\end{array}$} & - Awareness of territory & $2,7,8,10$ \\
\hline & - Involvement of different levels of government & 3,12 \\
\hline & - Spatial tool for coordination & 2,4 \\
\hline & - Acknowledgement and use of territorial potentials & 2,3 \\
\hline & - Co-production of knowledge, knowledge transfer & 4,11 \\
\hline & - Existing shared territorial knowledge & 7,12 \\
\hline & - Evidence of larger territorial context & Stakeholders workshop \\
\hline & - Spatially differentiated policies & Stakeholders workshop \\
\hline & - Territorial Impact Assessment & Stakeholders workshop \\
\hline & - Functional regions & Stakeholders workshop \\
\hline & - Territorial oriented evaluation & Stakeholders workshop \\
\hline & - Territorial challenges & Stakeholders workshop \\
\hline & - Building trust - permanent cooperation & Stakeholders workshop \\
\hline & - Eliminate barriers to cooperate & Stakeholders workshop \\
\hline
\end{tabular}

\footnotetext{
${ }^{\text {a }}$ Each of the numbers below refers to one of the 12 case studies, as indicated in footnote 7. Those features that emerged
} during the "Stakeholders workshop" are marked accordingly. 
Table 3. List of territorial governance inhibitors derived from the case study analysis

\begin{tabular}{|c|c|c|}
\hline Dimension & TG Inhibitors & Case studies $^{\mathbf{a}}$ \\
\hline \multirow{5}{*}{$\begin{array}{l}\text { 1. Coordinating } \\
\text { actions of actors } \\
\text { and institutions }\end{array}$} & - Lack of institutional capacity / stability & $2,4,6,8,9,12$ \\
\hline & - Scarce cooperation between public authorities & 6,11 \\
\hline & - Lack of financial autonomy & 9 \\
\hline & - Power struggles & $4,10,11$ \\
\hline & - Unclear assignation of responsibilities & $2,3,5,6,8$ \\
\hline \multirow{5}{*}{$\begin{array}{l}\text { 2. Integrating policy } \\
\text { sectors }\end{array}$} & - Lacking or inappropriate mechanisms for coordination & $5,9,10,11$ \\
\hline & - Sectoral rationale dominating & $1,2,4,12$ \\
\hline & - Lack of institutional capacity / stability & 9 \\
\hline & - Scarce cohesion among actors & $3,7,8,10$ \\
\hline & - Lack /ineffectiveness of integrating spatial tools & $4,9,11$ \\
\hline \multirow{7}{*}{$\begin{array}{l}\text { 3. Mobilising } \\
\text { stakeholder } \\
\text { participation }\end{array}$} & - Late or no involvement of stakeholders & 2,10 \\
\hline & - Involvement of non-cooperative stakeholders & 6,8 \\
\hline & - Exclusion / limited involvement of certain stakeholders & 6 \\
\hline & - Hegemony of politicians over the process & $2,10,11$ \\
\hline & - Limited communication among stakeholders & $6,10,11$ \\
\hline & - Limited communication towards the outside world & 2 \\
\hline & - Weak civic actors involvement & 9 \\
\hline \multirow{6}{*}{$\begin{array}{l}\text { 4. Being adaptive to } \\
\text { changing contexts }\end{array}$} & - Absence of feedback procedures & 2 \\
\hline & - Lack of institutional capacity / stability & 9,10 \\
\hline & - Prejudice or limited strategic thinking & 2,8 \\
\hline & - Uncertain/blurred strategy & 1 \\
\hline & - Rigidity of governance structure & 8,9 \\
\hline & $\begin{array}{l}\text { - Negative influence by people in charge of } \\
\text { responsibilities }\end{array}$ & 9 \\
\hline \multirow{5}{*}{$\begin{array}{l}\text { 5. Realising place- } \\
\text { based/ territorial } \\
\text { specificities and } \\
\text { impacts }\end{array}$} & - territorial scope disputed & $1,2,5,6,10$ \\
\hline & - lack of structured institutional framework & 9,12 \\
\hline & - time constrains & 11 \\
\hline & - limited use of existing territorial knowledge & $1,2,6,10$ \\
\hline & - excessive complexity of programming tools & 12 \\
\hline
\end{tabular}

\footnotetext{
a Each of the numbers below refers to one of the 12 case studies, as indicated in footnote 7.
} 
Transferability of territorial governance features The discussion on territorial governance transferability presented above suggests additional guiding questions concerning the territorial governance features emerging from the case studies, i.e. under which conditions each of them may constitute a trigger for learning in other contexts, how could it be possibly transferred and through whom. In order to provide an answer to these questions, each case study analyst was asked to assess the identified features of good territorial governance in relation to the various interactive resources that might potentially be helpful to transfer each of them from one context to another.

The collected information was aggregated under the same logic as the one adopted above for the abstraction of the general territorial governance promoters and inhibitors, and then verified during the Stakeholder's workshop. In this way, it was possible to link each promoter in the list to the specific group of stakeholders that usually manage those interactive resources that were identified as potentially useful for its transfer. In particular, those promoters that were assessed as more easily transferrable through practices of implementation were primarily addressed to practitioners; those that seemed to require techniques and methods for policymaking tools were addressed to policy-makers; and those that were indicated as needing the codification of rules for structuring territorial governance were addressed to decision-makers. Finally, the promoters whose transfer was considered to potentially occur through ideas and principles were addressed to all the categories of stakeholders (see table 4).

Table 4. Territorial governance promoters organized by interactive resources and target audiences

\begin{tabular}{|c|c|c|c|}
\hline $\begin{array}{l}\text { Practices of } \\
\text { implementation } \\
\text { (practitioners) }\end{array}$ & $\begin{array}{l}\text { Techniques and } \\
\text { methods for policy- } \\
\text { making tools } \\
\text { (policy-makers) }\end{array}$ & $\begin{array}{l}\text { Rules for structuring } \\
\text { territorial governance } \\
\text { (decision-makers) }\end{array}$ & $\begin{array}{l}\text { Ideas and principles } \\
\text { (all stakeholders) }\end{array}$ \\
\hline $\begin{array}{l}\text { Organizational } \\
\text { routines favour- } \\
\text { ing cross-sector } \\
\text { fertilisation }\end{array}$ & $\begin{array}{l}\text { - Effective strategic } \\
\text { framework - strategies }\end{array}$ & $\begin{array}{l}\text { - Political support to } \\
\text { policy integration } \\
\text { at the appropriate } \\
\text { territorial scale }\end{array}$ & $\begin{array}{l}\text { - Strong political } \\
\text { commitment towards } \\
\text { a shared territorial } \\
\text { vision }\end{array}$ \\
\hline $\begin{array}{l}\text { Involvement of } \\
\text { relevant public and } \\
\text { private stakeholders }\end{array}$ & $\begin{array}{l}\text { - Institutional capacity } \\
\text { - qualified staff }\end{array}$ & $\begin{array}{l}\text { - Spatial tool favouring } \\
\text { sectoral integration }\end{array}$ & $\begin{array}{l}\text { - Win-win situation } \\
\text { - interest }\end{array}$ \\
\hline $\begin{array}{l}\text { - Common goals, } \\
\text { common history }\end{array}$ & $\begin{array}{l}\text { - Follow-up } \\
\text { - monitoring }\end{array}$ & $\begin{array}{l}\text { - Balance between } \\
\text { flexibility and legal } \\
\text { certainty }\end{array}$ & $\begin{array}{l}\text { - Compatible policy } \\
\text { sectors }\end{array}$ \\
\hline - Motivation & $\begin{array}{l}\text { - Stability of coopera- } \\
\text { tive experiences }\end{array}$ & $\begin{array}{l}\text { - Code of conduct } \\
\text { - guidelines }\end{array}$ & $\begin{array}{l}\text { - Rationale catalysing } \\
\text { integration }\end{array}$ \\
\hline - Capacity of negotiation & $\begin{array}{l}\text { - Pro-active public } \\
\text { organisation }\end{array}$ & $\begin{array}{l}\text { - Leadership at the right } \\
\text { level }\end{array}$ & $\begin{array}{l}\text { - Acknowledgement of, } \\
\text { and integration with, } \\
\text { a multi-level policy } \\
\text { framework }\end{array}$ \\
\hline $\begin{array}{l}\text { Effective means } \\
\text { of communica- } \\
\text { tion/dissemination of } \\
\text { information }\end{array}$ & $\begin{array}{l}\text { - Mechanisms allowing } \\
\text { for broad stakeholders' } \\
\text { involvement }\end{array}$ & $\begin{array}{l}\text { - High level of } \\
\text { accountability }\end{array}$ & - Quality of motivation \\
\hline
\end{tabular}




\begin{tabular}{|c|c|c|c|}
\hline $\begin{array}{c}\text { Practices of } \\
\text { implementation } \\
\text { (practitioners) }\end{array}$ & $\begin{array}{l}\text { Techniques and } \\
\text { methods for policy- } \\
\text { making tools } \\
\text { (policy-makers) }\end{array}$ & $\begin{array}{l}\text { Rules for structuring } \\
\text { territorial governance } \\
\text { (decision-makers) }\end{array}$ & $\begin{array}{l}\text { Ideas and principles } \\
\text { (all stakeholders) }\end{array}$ \\
\hline $\begin{array}{l}\text { How to motivate } \\
\text { stakeholder (vision, } \\
\text { benchmarking) }\end{array}$ & $\begin{array}{l}\text { - Information flow } \\
\text { ensured }\end{array}$ & $\begin{array}{l}\text { - Multi-annual } \\
\text { programming }\end{array}$ & $\begin{array}{l}\text { - Clear and uncontested } \\
\text { leadership }\end{array}$ \\
\hline $\begin{array}{l}\text { - Usage of } \\
\text { various mechanisms of } \\
\text { participation }\end{array}$ & - Feedback procedures & $\begin{array}{l}\text { Power to decide } \\
\text { change at the right } \\
\text { level }\end{array}$ & $\begin{array}{l}\text { - Self-committed } \\
\text { leadership }\end{array}$ \\
\hline $\begin{array}{l}\text { - Exchanging best } \\
\text { practices to understand } \\
\text { the right amount of } \\
\text { adaptation }\end{array}$ & $\begin{array}{l}\text { - Methods for attracting } \\
\text { change }\end{array}$ & $\begin{array}{l}\text { - Role of people } \\
\text { in charge of } \\
\text { responsibility }\end{array}$ & $\begin{array}{l}\text { - Ownership of } \\
\text { questions }\end{array}$ \\
\hline $\begin{array}{l}\text { - Involvement, participa- } \\
\text { tion, commitment }\end{array}$ & $\begin{array}{l}\text { - Territorial Impact } \\
\text { Assessment }\end{array}$ & $\begin{array}{l}\text { - Institutional mecha- } \\
\text { nisms that favour } \\
\text { learning }\end{array}$ & $\begin{array}{l}\text { - Adaptive management } \\
\text { (flexibility, room to } \\
\text { change direction) }\end{array}$ \\
\hline $\begin{array}{l}\text { - Co-production of } \\
\text { knowledge and } \\
\text { knowledge transfer }\end{array}$ & & $\begin{array}{l}\text { - Institutional mecha- } \\
\text { nisms supporting } \\
\text { adaptivity }\end{array}$ & - Integrative holistic \\
\hline $\begin{array}{l}\text { - Experience in complex } \\
\text { programming }\end{array}$ & & $\begin{array}{l}\text { - Involvement of } \\
\text { different levels of } \\
\text { government }\end{array}$ & $\begin{array}{l}\text { - Being conscious and } \\
\text { being inspired }\end{array}$ \\
\hline $\begin{array}{l}\text { - Existing shared } \\
\text { territorial knowledge }\end{array}$ & & - Functional regions & $\begin{array}{l}\text { - Evidence of larger } \\
\text { territorial context }\end{array}$ \\
\hline $\begin{array}{l}\text { - Acknowledgement } \\
\text { and use of territorial } \\
\text { potentials }\end{array}$ & & $\begin{array}{l}\text { - Eliminate barriers to } \\
\text { cooperate }\end{array}$ & - Territorial challenges \\
\hline $\begin{array}{l}\text { - Building trust - per- } \\
\text { manent cooperation }\end{array}$ & & $\begin{array}{l}\text { - Spatially differentiated } \\
\text { policies }\end{array}$ & - Awareness of territory \\
\hline
\end{tabular}

\section{Conclusive remarks and future research perspectives}

By reflecting on what are the main features of good territorial governance and under which conditions they may constitute a trigger for learning in other contexts, this paper aimed at building an analytical bridge between the analysis of territorial governance empirical experiences and the production of policy relevant dissemination outputs. In so doing, it did not deal primarily with transferability as such (can/should we transfer territorial governance?), but mainly with a typology of potential transfer modes (how can we transfer it and through whom?).

On the basis of the presented conceptual framework, the author then presented some of the preliminary results of the ESPON TANGO project. When looking at territorial governance in order to understand how related practices and institutions can provide added value to achieving 
territorial cohesion, the project gathered relevant insights into current 'good practices' for territorial governance in Europe. Having been given the mandate to address specific questions regarding how territorial governance matters in producing a territorial development outcome or following-up on a larger policy goal such as territorial cohesion, the project team had not only to consider territorial governance from an analytical perspective, but also to integrate a normative one, namely in terms of what constitutes 'good' territorial governance, into the working definition of adopted as the main pivotal element of the research. By doing so it has been possible, on the basis of the materials collected through the case study analysis, to identify some generalizable lessons on 'what to do' and 'what not to do' in relation to territorial governance. This resulted into the definition of a list of general promoters and inhibitors of good territorial governance that may potentially provide fuel to the policy debate on the matter.

However, when it comes to policy relevant implications, it is important to stress that the various case studies constituting the evidence-base of the project address policies, programmes and projects insisting on various governance levels as well as located within different institutional and geographical context. Therefore, particular attention must be paid to identify 'for whom' the identified territorial governance promoters and inhibitors are considered to be 'good' or 'bad'. This raises particular challenges in relation to any in-depth discussion concerning the extent of their transferability into other contexts. Whereas the contribution presented a preliminary classification of the territorial governance promoters derived from the case studies according to the main interactive resources that may be useful for their transfer and, in turn, to the potential target audience to which the various promoters are mainly addressed to, such a distinction is by no mean exhaustive and requires further empirical research on the matter.

More in detail, as various critiques addressed to theories of policy transfer and lesson drawing (James \& Lodge, 2003; Bulkeley, 2006; Vettoretto, 2009; Peck, 2011; Stead, 2012) clearly remark, the 'filtering out' process of translating and combining features of good territorial governance from different contexts into one is a complex process that implies different degrees of adaptation. In a similar way, the 'filtering in' process through which specific territorial governance features may be taken on board in a different domestic context appears to be related to two intertwined dimensions, namely a process of adoption, that gives origin to policies/actions according to new contextual forms or shapes, and a degree of territorialisation, that is the relationship between these possible policies/actions and specific place-based issues at stake.

Finally, the authors would like to stress that neither this contribution nor the ESPON TANGO project aim at searching for 'one-size-fits-all' solutions concerning the transferability of territorial governance, but rather at building an evidence-based set of opportunities for innovation in territorial governance practices at different levels/in different contexts, from which various stakeholders may draw lessons according to their own peculiar needs and will.

\section{Acknowledgments}

The author would like to express his gratitude to the other member of the Politecnico di Torino local unit involved in the project, namely Nadia Caruso, Alberta De Luca, Francesca Governa, Umberto Janin Rivolin and Marco Santangelo, for the continuous proactive confrontation developed during the research work. Similarly, they would like to thank the other research teams that compose the ESPON TANGO transnational project group. 


\section{References}

Adams, N., Cotella, G. \& Nunes, R. (Eds) (2011), Territorial development, cohesion and spatial planning knowledge and policy development in an enlarged EU, London and New York, Routledge.

Alexander, E. R. (1995), How organizations act together, Luxembourg, Gordon and Breach.

Böhme, K. (2002), Nordic Echoes of European Spatial Planning, Stockholm, Nordregio.

Bulkeley, H. (2006), Urban sustainability: learning from best practice?, Environment and Planning A, 38(6), pp. 1029-1044.

CEC - Commission of the European Communities (2006). Communication from the Commission to the Council and the European Parliament on Thematic Strategy on the Urban Environment. COM (2005)718 Final. Office for Official Publications of the European Communities, Luxembourg.

CEC - Commission of the European Communities (2010), EUROPE 2020. A strategy for smart, sustainable and inclusive growth. $\operatorname{COM}(2010)$ 2020, Brussels, 3 March.

Cotella, G. \& Janin Rivolin, U. (2010), Institutions, discourse and practices: towards a multidimensional understanding of EU territorial governance, paper presented at the XXIV AESOP Congress Space is Luxury, Helsinki, 7-10 July.

Cotella, G. \& Janin Rivolin, U. (2012), Europeanization of spatial planning through discourse and practice in Italy, dis $P, 186$, pp. 42-53.

Davoudi, S., E. Evans, F. Governa, and M. Santangelo (2008). "Territorial Governance in the Making. Approaches, Methodologies, Practices”, in: Boletin de la A.G.E.N, No 46 - 2008.

Dolowitz, D. \& Marsh, D. (2000), Learning from abroad: the role of policy transfer in contemporary policy-making, Governance, 13(1), pp. 5-24.

ESPON (2006), ESPON 2.3.2 Governance of Territorial and Urban Plicies from EU to Local Level. Final Report. ESPON Coordination Unit, Luxembourg.

ESPON (2012), ESPON TANGO - Territorial Approaches for New Governance. Final Report. ESPON Coordination Unit, Luxembourg.

Faludi, A (2012). Multi-level (Territorial) Governance. Three Criticisms. Planning Theory \& Practice, Vol. 13, Issue 2, 2012 DOI: 10.1080/14649357.2012.677578

Gualini, E. (2001), Planning and the intelligence of institutions. Interactive approaches to territorial policy-making between institutional design and institution-building, Aldershot, Ashgate.

Gualini, E. (2008). 'Territorial cohesion' as a category of agency: the missing dimension in the EU spatial policy debate, European Journal of Spatial Development, Refereed Articles, 28, pp. 1-22 http://www.nordregio.se/EJSD/refereed28.pdf.

Gupta, J., Termeer, C., Klostermann, J., Meijerink, S., van den Brink, M., Jong, P., Nooteboom, S. and Bergsma, E. (2010). The Adaptive Capacity Wheel: a method to assess the inherent characteristics of institutions to enable the adaptive capacity of society. Environmental Science \& Policy, 13 (6), pp. 459-471.

Healey P. (1997). Collaborative Planning: Shaping Places in Fragmented Societies, Mac-Millan, Basingstoke, London.

Healey, P. (1999), Institutionalist analysis, communicative planning and shaping places, Journal of Planning Education \& Research, 19(2), pp. 111-122.

Healey, P. (2006), Transforming governance: challenges of institutional adaptation and a new politics of space, European Planning Studies, 14(3), pp. 299-320. 
Holzinger, K. \& Knill, C. (2005), Causes and conditions of cross-national policy convergence, Journal of European Public Policy, 12(5), pp. 775-796.

Hooghe, L. and G. Marks (2001). Multi-level governance and European integration Lanham MD, Rowman \& Littlefield.

Hooghe, L., and Marks, G. (2003). "Unraveling the Central State, but How? Types of Multi-Level Governance. The American Political Science Review, Vol. 97, No. 2 (May 2003). Pp-233-243.

James, O. \& Lodge M. (2003), The limitations of 'policy transfer' and 'lesson drawing' for public policy research", Political Studies Review, 20(1), pp. 179-193.

Janin Rivolin, U. (2010), EU territorial governance: learning from institutional progress, European Journal of Spatial Development, refereed articles, 38, pp. 1-28.

Janin Rivolin, U. (2012), Planning systems as institutional technologies: a proposed conceptualization and the implications for comparison, Planning Practice and Research, 27(1), pp. 63-85.

Janin Rivolin U. \& Cotella G. (2014), A conceptual device for spreading (good) territorial governance in Europe, ESPON Scientific Report, Luxembourg, ESPON.

Jordan, A. (2008). The governance of sustainable development, Environment and Planning C: Government and Policy 2008, volume 26, pp. 17-33.

Knill, C. \& Lehmkuhl, D. (1999), How Europe matters. Different mechanisms of Europeanization, European Integration Online Papers, 7 (3), http://eiop.or.at/eiop/texte/1999-007.htm.

Lenschow, A. (2006), Europeanization of public policy, in Richardson, J. (Ed.), European Union. Power and policy making, Abingdon, Routledge, pp. 55-71.

Moroni, S. (2010), An evolutionary theory of institutions and a dynamic approach to reform, Planning Theory, 9(4), pp. 275-297.

Moulaert, F. (2005), Institutional economics and planning theory. A partnership between ostriches, Planning Theory, 4(1), pp. 21-32.

Olsen, J. P. (2002), The many faces of Europeanization, Journal of Common Market Studies, 40(5), pp. 921-952.

Peck, J. (2011), Geographies of policy: from transfer-diffusion to mobility-mutation, Progress in Human Geography, 35(6), pp. 773-797.

Pierre, J. and Peters, B. (2000) Governance, Politics and the State. Macmillan: Basingstoke, Hants.

Radaelli, C. M. (2004), Europeanization: solution or problem?, European Integration Online Papers, 8(16), http://eiop.or.at/eiop/texte/2004-016.htm.

Stead, D. (2012), Best practices and policy transfer in spatial planning, Planning Practice and Research, 27(1), pp. 103-116.

Stoker, G (1998). Governance as theory: five propositions. UNESCO 1998. Blackwell.

Verma, N. (Ed) (2007), Institutions and planning, Oxford, Elsevier.

Vettoretto, L. (2009), A preliminary critique of the best and good practices approach in European spatial planning and policy-making”, European Planning Studies, 17(7), pp. 1067-1083.

Wishlade, F., Yuill, D. \& Mendez, C. (2003), Regional policy in the EU: a passing phase of Europeanisation or a complex case of policy transfer?, Regional and Industrial Policy Research Paper 50 (Glasgow, European Policies Research Centre - University of Strathclyde),www.eprc.strath. ac.uk/eprc/Documents/PDF_files/RIPR\%2050\%20ESRC.pdf

Wolman H. L., Ford C. C. \& Hill E. W. (1994), Evaluating the success of urban success stories, Urban Studies, 31(6), pp. 835-850.

Wolman, H. L., \& Page, E. (2002), Policy Transfer among local governments. An information theory approach, Governance, 15(4), pp. 477-501. 
http://rcin.org.pl 